\title{
Development of Psychology Based on Online with Edward Personality Preference Schedule and High Level Indonesian Collective Intelligence Test
}

\author{
Richard Juan Putra Sudarto, Erdhi Widyarto Nugroho, Hendra Prasetya \\ Department of Information System, Faculty of Computer Science, \\ Soegijapranata Catholic University, Semarang, Indonesia \\ Richardjuan95@gmail.com,erdhi@unika.ac.id,hendra@unika.ac.id
}

\begin{abstract}
Online psychotic are developed to keep up with current technological advancements. Application of Psychotest Development Based on Online with Edward Personality Preference Schedule and Highlevel Indonesian Collective Intelligence Test, developed for the benefit of the Soegijapranata Center for Applied Psychology. Making the application "Psychotest Development Based on Online with Type of EPPS and High TIKI" is motivated by the director's vision to be able to advance PPT Soegijapranata. In the process of creating an application design, sources were obtained from the director of the Center for Applied Psychology at Uneg Soegijapranata, the design obtained was the number of users, application flow, and mockup design. The goal to be achieved is to change the manual process to use technology. When testing 30 respondents, it was found that the Psychotest Development Application Based Online with EPPS and TIKI Types was quite helpful and made the test process simple.
\end{abstract}

Keyword- EPPS, Psychological Tests, Online Psychology, Tiki - Tinggi

\section{INTRODUCTION}

The development of the world today utilizes information technology that is developing rapidly. Information Technology is a technology used to process data, including processing, obtaining, compiling, storing, manipulating data in various ways to produce quality information, namely relevant, and accurate information, which is used for personal, business and government purposes and is a relevan information for decision making [1]. Psychological tests or psychological tests are tests carried out to measure aspects psychologically in this case, the measured tendency is behavior [2]. Psychological tests are conducted to find out various types of individual abilities, namely, knowing mental aspects (psychic), supporting aspects (achievement, ability, and personality).

In general, psychological tests are carried out in writing, but several psychological institutions that use technology to create website-based online psychologies. Based on several psychology expert systems that need to be considered in making a manual test mix into the technology system, consisting of three main modules, namely: knowledge base, working memory and inference engine [3].

Many aspects need to be considered, to develop online psychology. According to Linden in Candiasa (2003) how to identify several educational models that are systemized or computerized, namely: automatic test design adaptive tests, item test writing systems, and multimedia tests [4]. The application "Psychotest Development Based on Online with Epps and Tiki Types" is used as an online test media, and also to print the final report that will be given to participants. The EPPS test (Edwards Personal Preference Schedule), was built to test a series of personality variables drawn from Murray's list of manifest (need) needs (1938) [5]. The EPPS test is included as a personality or 
intelligence test. To see one's needs, namely the special needs of someone [6].

The TIKI test - high (High-Level Indonesian Collective Test) has 10 chapters consisting of, counting numbers, part combinations, relationship words, nonverbal abstractions, numerical series, researching, forming objects, exclusion of words, an analogy of words, hidden forms, word formation [7]. Intelligence tests are generally in the form of IQ (Intelligence Quotient), but there are also intelligence tests that do not produce IQ, in the form of a level (Raven). Intelligence / Intellectual Intelligence is the ability of an individual to be able to act in a directed, rational way of thinking and can deal with his environmental conditions effectively [8].

\section{Test EPPS}

\section{LITERATUR REVIEW}

EPPS Test (Edward Personality Preference Schedule) is a personality test that can measure a person's personality level. The EPPS test is developed according to $\mathrm{H}$. A Murray's personality theory, which includes 15 needs that each human has [9]. Edward prepared several items according to those needs. The EPPS test can reveal the tendency of encouragement and the needs of someone [10]. This test is usually used by people who will enter the world of work, in the application to enter work or increase their position.

The instructions in EPPS are done using Testee, which is choosing one of the two statements that exist (A and B). The following aspects can be concluded from the EPPS test EPPS is generally categorized as a power test which is a test that is not limited in time in the process. So, the emphasis on completing tasks is not the time. In doing EPPS tests all items must be answered, if there is only one item that is missed then accurate interpretation cannot be done. EPPS tests can be given individually or classically. The initial background is for counseling and orientation is for normal people (Karmiyati \& Suryaningrum, 2005) [11].
Table 2.1 Need test EPPS

\begin{tabular}{|c|c|c|}
\hline No & Need & Penjelasan \\
\hline 1 & Achievement & Kebutuhan berprestasi \\
\hline 2 & Deference & $\begin{array}{l}\text { Kebutuhan menyesuaikan } \\
\text { diri }\end{array}$ \\
\hline 3 & Order & $\begin{array}{l}\text { Kebutuhan teratur, rapi dan } \\
\text { sesuai perencanaan }\end{array}$ \\
\hline 4 & Exhibition & $\begin{array}{ll}\text { Kebutuhan } & \text { untuk } \\
\text { menunjukkan diri } & \end{array}$ \\
\hline 5 & Autonomy & Kebutuhan untuk mandiri \\
\hline 6 & Affiliation & Kebutuhan berempati \\
\hline 7 & Intraception & $\begin{array}{l}\text { Kebutuhan perhatian } \\
\text { terhadap sesama }\end{array}$ \\
\hline 8 & Succorance & $\begin{array}{l}\text { Kebutuhan akan hubungan } \\
\text { sosial }\end{array}$ \\
\hline 9 & Dominance & $\begin{array}{l}\text { Kebutuhan untuk } \\
\text { memimpin }\end{array}$ \\
\hline 10 & Abasement & Kebutuhan berkompromi \\
\hline 11 & Nurturance & $\begin{array}{l}\text { Kebutuhan memberi } \\
\text { perhatian }\end{array}$ \\
\hline 12 & Change & Kebutuhan berubah \\
\hline 13 & Endurance & $\begin{array}{l}\text { Kebutuhan keuletan dan } \\
\text { kegigihan }\end{array}$ \\
\hline 14 & Heterosexuality & $\begin{array}{l}\text { Kebutuhan bergaul dengan } \\
\text { lawan jenis }\end{array}$ \\
\hline 15 & Aggression & $\begin{array}{l}\text { Kebutuhan bertentangan } \\
\text { dengan orang lain }\end{array}$ \\
\hline
\end{tabular}

\section{Test Tiki - Tinggi}

Andrew Brider (in Azwar, 2008: 4) says that intelligence can be assumed to be like electricity, easy to measure but almost impossible to define [12]. William Stern argues that testing intelligence is largely based on derivation, education or a less influential environment [13]. Intelligence tests are the embodiment of power in human beings, which affects one's abilities in various fields. Spearman made a formula called "general ability" which plays a role in storing and binding back information, arranging concepts, capturing relationships and making conclusions, processing materials and composing a new combination of these materials. 


\section{Arsitekstur aplikasi berbasis Web}

Web-based applications can be designed in a simple or complex way, basically, webbased applications run using the Client-Server mechanism [14]. How the client-server works, from the client-side, does not require sophisticated technology specifications, because most of the process is done on the server. From the server-side, where there is a web server software. This computer is a place to store client data and can be accessed from anywhere.

\section{PHP}

PHP stands for "Hypertext Preprocessor", an open-source programming language used for web development and can be embedded into HTML. Most of the syntax in PHP is similar to C, Java, and Perl, but in PHP there are several distinguishing functions from other languages, PHP runs on the server-side, generates HTML, then sends to clients [15]. Currently, PHP can be run on most operating systems such as Linux, Windows, Mac OS X, and others. PHP also supports almost all web servers such as Apache, Nginx, Lighttpd, and others.

\section{Flowchart}

\section{METHOD}

Application "Development of Online Based Psychotes with Types of EPPS and TIKI" Designed based on a flowchart that will be used by 3 type users, namely staff, psychologists and participants.

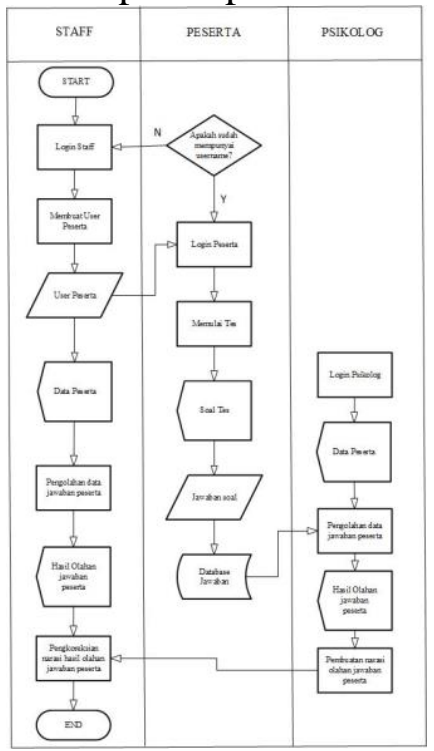

Figure 3.1 Flowchart Application

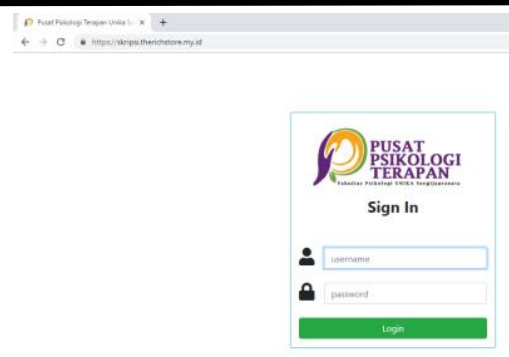

Figure 3.2 Login Page

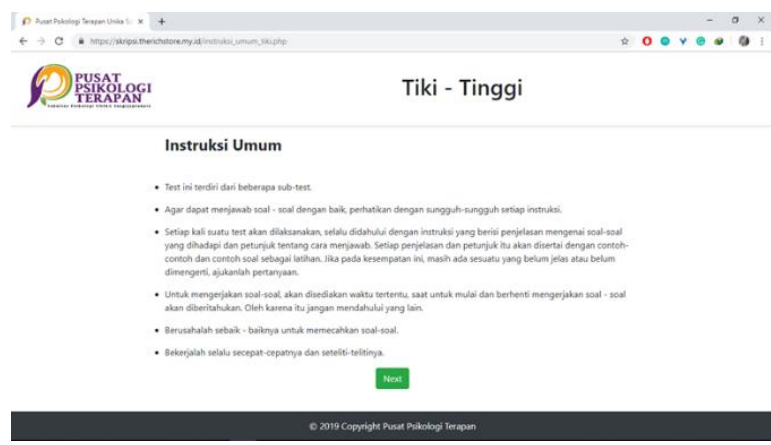

Figure 3.3 Instruction Page

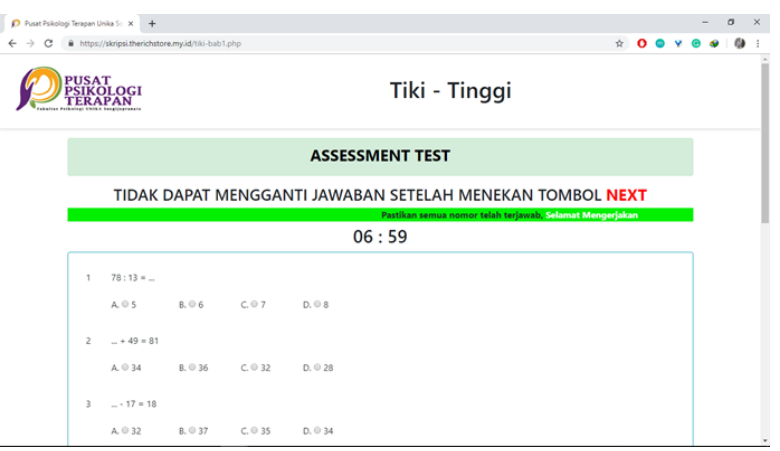

Figure 3.4 question page

In the login view of the psychologist, you can immediately see the results of the test. Furthermore, psychologists match various tests to be able to provide conclusions for user test before starting to work on the problem, given the instruction page to be able to work on the next chapter or test.

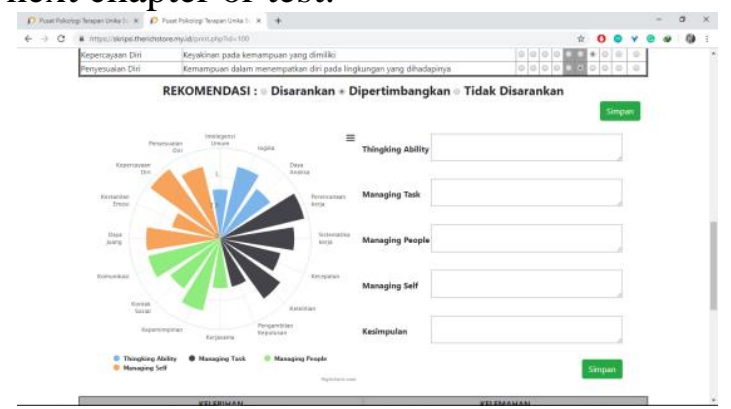

Figure 3.5 Report Page 


\section{RESULTS AND DISCUSSION \\ Profile responden}

Of the 30 respondents who participated in the trial application of Psychotest Development Based on Epps and Tiki Types, we can find out the number of respondents based on age, gender, education and experience according to the picture below.

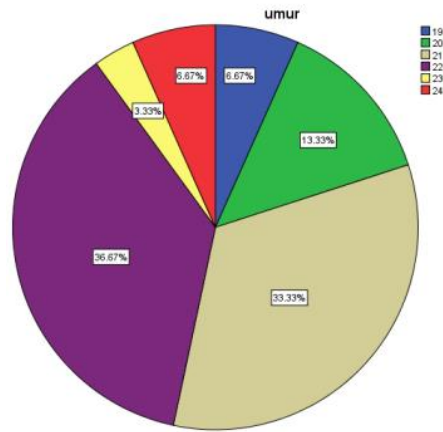

Figure 4.1 Responden by age

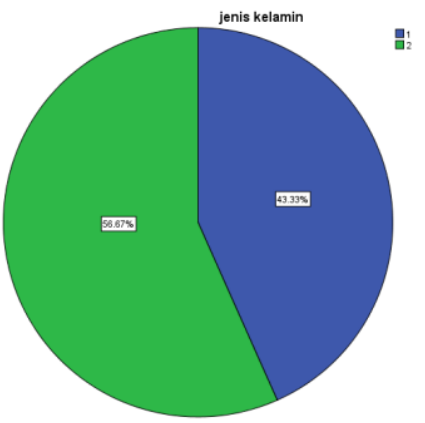

Figure 4.2 Responden by Gender

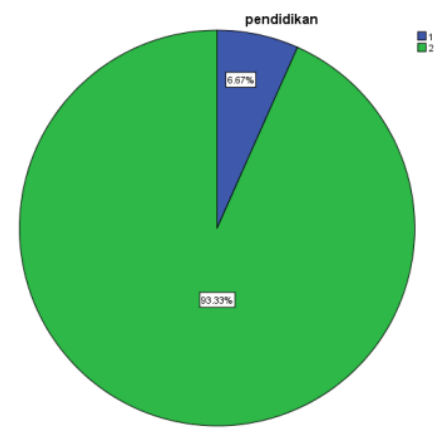

Figure 4.3 responden by Education

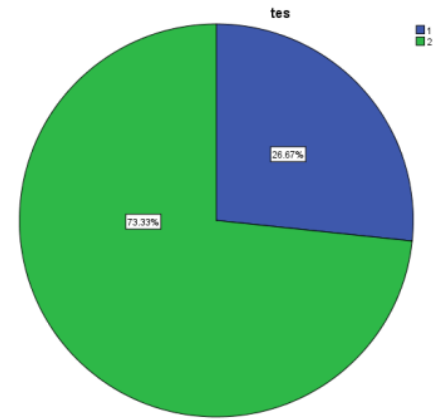

Figure 4.4 Responden by knowing psychotes online

\begin{tabular}{|c|c|c|}
\hline \multicolumn{3}{|c|}{ Table 4.1 Table Reliability } \\
\hline Variable & $\begin{array}{c}\text { Cronbach's } \\
\text { Alpha Based } \\
\text { on } \\
\text { Standardized } \\
\text { Items }\end{array}$ & Keterangan \\
\hline $\begin{array}{c}\text { Kemudahan } \\
\text { (A) }\end{array}$ & .703 & Acceptable \\
\hline $\begin{array}{c}\text { Kebergunaan } \\
\text { (B) }\end{array}$ & .503 & Poor \\
\hline $\begin{array}{c}\text { Kenyamanan } \\
\text { (C) }\end{array}$ & .831 & Good \\
\hline
\end{tabular}

Test the reliability of variables $\mathrm{A}, \mathrm{B}$, and $\mathrm{C}$, to determine the information in table 4.2 based on, George and Mallery (2003) rules of thumb: "_> .9 - Excellent, _> .8 - Good,_> .7 - Acceptable , _> .6 - Questionable, _> .5 Poor, and _ <.5 - Unacceptable "[18]. The Reliability test is a measuring instrument used in research to determine the consistency of test results or questionnaires [17]. The results of the questionnaire for reliability testing for variable A are declared Acceptable because the value of Cronbach's Alpha shows the number, .703, the value of Cronbach's Alpha is obtained by testing similar variables using the Reliability Analyze menu on SPSS. The reliability test for variable B was stated as Poor with the value of Cronbach's Alpha .503. The reliability test results on variable $\mathrm{C}$ are declared Good with the value of Cronbach's Alpha .803.

\section{CONCLUSION}

The conclusion from this research the application of Psychotest Development Application Based on Epps And Tiki Online can be used and easily understood by users. The appearance and process of the application are in accordance with the draft given by the director of the applied psychology center, UniSegijapranata. This statement was obtained from a questionnaire that was attended by 30 respondents. Psychological 
tests can be done online. And the results are faster and more accurate than manual methods.

\section{ACKNOWLEDGEMENT}

The writer is a student of Unika Soegijapranata information system which is currently studying in semester eigh.

\section{REFERENCES}

[1] W. Wardiana, "Perkembangan Teknologi Informasi di Indonesia $*$ )," Semin. dan Pameran Teknol. Inf. 2002, 2002.

[2] T. C. Edukasi, Psikotes 2014 Terlengkap, Cetakan Pe. Jakarta: PT. Tangga Pustaka, 2014.

[3] D. Andayati, "SISTEM PAKAR DALAM BIDANG PSIKOLOGI Dina Andayati," Semin. Nas. Apl. Sains Teknol. Periode IIIISSN 1979-911X, no. November, pp. 286-293, 2012.

[4] K. Setemen, "Pengembangan evaluasi pembelajaran online," Pendidik. dan Pengajaran, vol. 43, pp. 207-214, 2010.

[5] C. F. Dicken, "SIMULATED PATTERNS ON THE EDWARDS PERSONAL PREFERENCE SCHEDULE 1," J. Appl. Psychol., vol. 43, no. 6, pp. 372-378, 1959.

[6] H. G. A. Isnandani, "BAB I," TESIS, pp. 1-5, 1953.

[7] M. S. Nur'aeni, S.Psi., "TES PSIKOLOGI : Tes Inteligensi dan Tes Bakat."

[8] L. Rahmasari, "Pengaruh Kecerdasan Intelektual , Kecerdasan Emosi dan Kecerdasan Spiritual Terhadap Kinerja Karyawan," Maj. Ilm. Inform., vol. no 1, vol, 2012.

[9] M. Murray, "PERSONOLOCI MURRAY Disarikan oleh : Ehan," pp. 1-41, 1930.

[10] E. N. Sari et al., "ERVINA NURMALITA SARI, 2017 PROFIL KEPRIBADIAN SISWA YANG BERLATAR BELAKANG KELUARGA PHYSICALLY BROKEN HOME BERDASARKAN EDWARD
PREFERENCE

SCHEDULE

Universitas Pendidikan Indonesia I.upi.edu perpustakaan.upi.edu," pp. 19, 2017.

[11] C. Suryaningrum, "COGNITIVE BEHAVIOR THERAPY (CBT) UNTUK MENGATASI GANGGUAN OBSESIF KOMPULSIF," J. Ilm. Psikol. Terap., vol. 01, no. 01, p. 11, 2013.

[12] R. WIDYASTUTI, "Hubungan motivasi belajar dan hasil tes intelegensi dengan prestasi belajar tesis," TESIS, 2010.

[13] W. S. Winkel, "Miyah vol.xi no. 02 agustus tahun 2015," no. 02, pp. 168179, 2015.

[14] A. Solichin, "Pemrograman Web dengan PHP dan MySQL."

[15] A. Lena and K. Ratna, "Pengertian PHP dan MySQL," Ilmu Teknol. Inf., pp. 23, 2008. 